\section{Cultural chauvinism}

Europe and the United States are haggling over airline ownership and television programmes.

EVERYBODY knows that the most cherished symbols of national sovereignty are a national airline and a television broadcasting network. In the $1960 \mathrm{~s}$, when independent governments were being created every few months, subsidized airlines and television stations were springing into being at a similar rate. Well-established governments, then, were scornful of this almost ritual hankering after the empty trappings of statehood. Yet it is now apparent that even the most mature governments are not immune from the same self-deception. How else can be explained the smouldering row between the United States and the governments of Western Europe over the ownership of US airlines and, separately, the content of European television broadcasts?

The circumstances are mystifying. Early in the decade, the Reagan administration decreed that US airlines should be deregulated in the sense that those with aircraft meeting specified standards of safety should be allowed to fly whichever routes they chose, charging whatever fares seemed to them to be economic. There followed a brief period during which new US airlines sprang into being and travellers were able to cross North America more cheaply by air than by any other means. But the prospect that competition would provide the smaller airlines with endless opportunities for growth proved hollow; those still surviving have mostly found niches as commuter and feeder airlines, while even the major US airlines have found their mutual competition financially debilitating.

That is partly why Northwest Airlines calculated that it could retain its independence only by seeking foreign investment (eagerly offered by the Netherlands airline KLM) and why the staff of United Airlines has teamed up with British Airways to buy the business from its present owners. But now, to everybody's consternation, the US Department of Transportation has decreed that KLM's proposed stake in Northwest Airlines must be reduced, casting a shadow on the British Airways deal as well. US law requires that no more than a quarter of the stock of US airlines should be owned by foreigners, but the US government has now taken the administrative view that foreigners must not acquire undue influence over US airlines by lending them money either.

The other side of this coin is the restriction of the content of television broadcasts proposed by the European Commission, with the enthusiastic support of several member governments of the European Community. Briefly, the commission proposes that only 15 per cent of the material broadcast by European television stations should come from outside Europe. Mrs Carla Hills, the US Trade Representative, has been in Europe lobbying against this intended regulation on behalf of the US television producers, whose business may be damaged if
Western European television watchers cannot enjoy what has become their usual diet of US programmes.

Both arrangements are unreasonable restraints on trade, and should be openly recognized as such. The time has long since gone when commercial aircraft were essential components of a country's strategic power; to restrict foreign ownership is to restrict competition, thus ensuring that domestic travellers in the United States pay more than would be necessary. The proposed restriction of the foreign content of European television broadcasts will have the same effect; even when people do not have to pay for the privilege of watching television, extra costs will somehow have to be passed on. But is it not worth paying extra to retain Europe's cultural purity? That is the argument that beguiles governments, but can it make sense in a rapidly shrinking world?

\section{Sale delayed}

The postponed timetable for selling Britain's electricity industry will increase uncertainty and reduce the price.

THE plan to sell Britain's electricity industry to private investors was never likely to be smoothly carried through, but the British government's decision last week that its timetable must be postponed by up to six months is a substantial setback, however much ministers may make light of it. There is a political risk; the timetable may now be so stretched out as to confuse the next general election. But there are important issues of principle still to be settled. Among other things, but to nobody's surprise, it is proving difficult to hammer out contractual arrangements between the supply companies, which are due to become retailers of electricity and which will be the first to be sold, and the generating companies, which will own existing power stations, which will be free to build more (as will be the supply companies) and will also enjoy the right to sell direct to industrial consumers of electricity.

That these questions are not simple goes without saying. Although the British government's intention seems to be that the balance between the supply and generating companies should eventually be determined by economics and market forces, the transition from the here-and-now must necessarily be somewhat prescribed. Otherwise, the uncertainties would make the chances of selling either of the two halves of the industry, let alone the National Grid (which is to be owned jointly by the supply companies), at a price reflecting the value of the assets being transferred, small indeed. Even as things stand, and with the government's undertaking to continue owning Britain's first generation of nuclear power stations (and thus to shoulder the substantial decommissioning costs that will eventually arise), the uncertainties are so great that the whole industry is likely to be sold for far less than its present economic value. Some of the eventual owners will profit handsomely, but guessing which they are is, on present showing, mere guesswork. 